\title{
Transient pancytopenia associated with parvovirus infection in paroxysmal nocturnal haemoglobinuria
}

\author{
A.K. Lakhani, V. Malkovska, D.H. Bevan and M.J. Anderson ${ }^{1}$ \\ Haematology Department, St. George's Hospital, Blackshawe Road, Tooting, London SW17 and 'Department of \\ Medical Microbiology, University College London, University Street, London WC1E 6JJ, UK.
}

\begin{abstract}
Summary: A 25 year old woman with a 15-year history of paroxysmal nocturnal haemoglobinuria developed transient pancytopenia following infection with human parvovirus B19. This is the first report of transient pancytopenia in a patient with an acquired haemolytic anaemia due to parvovirus. The possible mechanism of pancytopenia in such a case is discussed.
\end{abstract}

\section{Introduction}

Infection with human parvovirus (HPV) B19 has been found to cause aplastic crises in hereditary haemolytic anaemias, including sickle cell disease, spherocytosis, pyruvate kinase deficiency and thalassaemia, probably via direct effects on rapidly-dividing erythroid cells in the bone marrow.' Paroxysmal nocturnal haemoglobinuria $(\mathrm{PNH})$ is an acquired disorder of the haemopoietic stem cell which leads to abnormal sensitivity of circulating blood cells to complement activation. Chronic intravascular haemolysis is the dominant clinical manifestation of this abnormality. Transient bone marrow aplasia due to parvovirus has not previously been described in acquired haemolytic anaemia. We describe a patient with PNH who developed transient bone marrow aplasia following parvovirus infection.

\section{Case report}

A 10 year old girl presented in 1971 with a history of pallor, lethargy, tiredness and passing dark urine. Investigations showed pancytopenia, haemoglobinuria and presence of haemosiderin in the urine. Ham's test confirmed the diagnosis of PNH. She required frequent blood transfusions initially but 3-4 times a year more recently. At the age of 25 she was admitted to hospital with a short history of myalgia, headache and lethargy. On examination she was apyrexial, anaemic and had a palpable spleen. A blood count

Correspondence: A.K. Lakhani, M.R.C.P., M.R.C.Path. Accepted: 16 December 1986 revealed pancytopenia (see Table I); aspirated bone marrow particles were hypocellular, and the few red cell precursors present were markedly dyserythropoietic. She was transfused with four units of plasma-reduced blood and made a rapid symptomatic recovery. Seven days later the peripheral blood counts began to improve and after 28 days she re-attained her steady-state values.

Parvovirus B19 genome was detected by DNA: DNA hybridization in the serum specimen obtained on admission. Convalescent serum taken 7 days later contained B19-specific IgM antibody but viral DNA was no longer detectable.

\section{Discussion}

Our findings suggest that short, severe, self-limited episodes of pancytopenia in PNH can be associated with parvovirus infection. Reports of transient pancytopenia in PNH are rare, but a similar case has been

Table I Haematological data

\begin{tabular}{|c|c|c|c|c|}
\hline & $\begin{array}{c}\text { On } \\
\text { admission }\end{array}$ & $\begin{array}{l}7 \text { days } \\
\text { later } \dagger\end{array}$ & $\begin{array}{l}28 \text { days } \\
\text { later }\end{array}$ & $\begin{array}{l}\text { Steady } \\
\text { state }\end{array}$ \\
\hline $\begin{array}{l}\text { Haemoglobin } \\
\text { concentration }(\mathrm{g} / \mathrm{dl})\end{array}$ & 5.7 & 9.6 & 10.2 & 10.2 \\
\hline White cell count $\times 10^{9} / 1$ & 1.0 & 3.7 & 6.2 & 4.2 \\
\hline $\begin{array}{l}\text { Granulocyte } \\
\text { count } \times 10^{9} / 1\end{array}$ & 0.54 & 2.7 & 4.8 & 2.8 \\
\hline Platelet count $\times 10^{9} / 1$ & 55 & 100 & 157 & 121 \\
\hline Reticulocytes \% & 0.2 & 1.4 & 4 & 7 \\
\hline
\end{tabular}

$\dagger$ after blood transfusion 
described. ${ }^{2}$ They are distinct from the chronic hypoplastic anaemia, lasting months or years, which is a common feature of PNH, and in which no evidence of parvovirus infection has been found. ${ }^{3}$ Most HPVassociated crises in hereditary haemolytic anaemias have selectively involved the red-cell series, with pancytopenia only seen in a single case of thalassaemia. ${ }^{4}$ However, recent studies inoculating normal

\section{References}

1. Blacklock, H.A. \& Mortimer, P.P. Aplastic crisis and other effects of the human parvovirus infection. In Prentice, H.G. (ed) Clinics in Haematology, Vol 13, no 3 W.B. Saunders, London, Philadelphia, Toronto, 1984. pp 679-691.

2. Crosby, W.H. Paroxysmal nocturnal haemoglobinuria: report of a case complicated by an aregenerative (aplastic) crisis. Ann Int Med 1953, 39: 1107-1117.

3. Young, N.S., Mortimer, P.P., Moore, J.G. \& volunteers with B19 have shown that a transient reduction in white cells and platelets is a common feature of parvovirus infection. ${ }^{5}$ The lesion of PNH leads to shortened survival of platelets and granulocytes as well as red cells, and under these conditions pancytopenia may be the likely outcome of parvovirus infection.

Humphreys, R.L. Characterization of a virus that causes transient aplastic crisis. J Clin Invest 1984, 73: 224-230.

4. Rao, K.R.P., Patel, A.R., Anderson, M.J. et al. Infection with parvovirus-like virus and aplastic crisis in chronic haemolytic anaemia. Ann Int Med 1983, 98, 930-932.

5. Anderson, M.J., Higgins, P.G., Davis, L.R. et al. Experimental parvoviral infection in humans. $J$ Infect Dis 1985, 152, 257-265. 